\title{
RISK OF CHILDREN'S VIOLENCE BY SOCIAL AND DEMOGRAPHICAL FACTORS IN SLUM AREA SURABAYA INDONESIA
}

\author{
Aristiana Prihatining Rahayu \\ University of Muhammadiyah Surabaya, Indonesia \\ aristianapr@yahoo.co.id
}

\begin{abstract}
Nowdays more and more cases of abuse against children, whether physical, verbal, emotional, or sexual. Some factors that could be the cause of abuse against children include family dysfunction, economic factors, and misperceptions about how to educate children. Based on data from the Ministry of Women and Children's Empowerment (Kemen PP \& Anak) per 2010, the number of 25 million Indonesian children has experienced various forms of abuse. The mean abuse is due to family economic pressures and poor parental understanding of parenting. Related to this issue, the Government has issued the Regulation of the Minister of Women Protection (PP) \& Child Protection (PA) Number 2 Year 2010 on National Action Plan for the Prevention and Handling of Abuse against Children. Areas prone to abuse against children, such as in densely populated areas, slums and remote villages. The research method is qualitative with analytical descriptive approach in data analysis. The results of data analysis in the form of exposure to some observed variables, and the relationship between these variables. In the study found that, residents who live in slums or densely populated vulnerable to abuse in children, whether physical abuse, psychological / emotional, and verbal abuse. Children with poorly educated / out-of-school parents, with no regular employment, low religious knowledge and practice are more at risk / more likely to experience abuse. Likewise with children whose parents marry young, the number of children and many have a dark past as victims of abuse in the care of their parents, also have a greater risk of becoming victims of abuse. Child abuse also causes non-fulfillment of children's access to the right to life, including the right to education services that cause children to drop out of school. In conclusion, there is a model of linkage between the risk of child abuse and social and demographic factors in the slums.
\end{abstract}

Keywords: child abuse, social factors, demography

\section{INTRODUCTION}

Every child has the right to survive, to grow and to develop and to be entitled to protection from all forms of abuse. The world of children is a world that children can enjoy without abuse, without fear so that children are able to express and actualize themselves positively in various forms. Currently, abuse is often found in children, whether physical, sexual, emotional abuse, or neglect of children. Some factors that could be the cause of abuse against children: Domestic abuse, family dysfunction, economic factors, and wrong perception of how to educate children. If in a family there is abuse involving the father, mother and other relatives, then it is quite possible that a child can not escape the abuse either. Children are often subjected to anger and other abusive behaviors from parents. A condition where the parent's role is not working properly. Dysfunction of a father who is unable to become a family leader and dysfunction of a mother who can not act as a guiding and caring person. Inability to play a role as a parent then brings the child into a chaotic family condition and is often the target of anger and other abuse from his family.

Abuse against children can also arise due to economic problems. The economic pressure is so severe that parents become stressful and vent their children. There are still many parents in this country who may not have enough food before marriage in educating children. Plus the wrong perception in educating children. There are some people who may think that pinching the body to slap the child's cheeks is something that should be done even in educating children to obey. This is actually a big mistake in educating the child and at the same time the parent's inability to communicate something good and not to the children.
A child who in childhood often got abuse or treatment from a parent, then when he grows up, he has the potential to become a parent candidate who also commonly acts of abuse (which he deems normal because he often experiences it from his parents first) to his children. Based on data from the Ministry of Women and Children's Empowerment (Kemen PP \& Anak) per 2010, the number of 25 million Indonesian children has experienced various forms of abuse. The average abuse is caused by the economic pressure of the family, so the parents take the burden of life to the child. The government has issued Regulation of the Minister of PP \& Children Number 2 of 2010. Areas prone to abuse against children, such as in densely populated areas, slums and remote villages. Almost 90 percent of parents who live in densely populated areas in Bandung do abuse against children (http://regional.kompas.com/read/2014/10/13).

National Commission for Child Protection (Komnas PA) called the complaint of violation of children's rights continue to increase. This is based on data collected by Data and Information Center (Pusdatin) Komnas Anak, in the period 2010-2015. Secretary General of Komnas PA, said the number of complaints in 2010 was 2,046, of which 42 percent were sexual crimes. In 2011 it became 2,467 cases, of which 52 percent were sexual crimes. While in 2012, there are 2,637 complaints that 62 percent of sexual abuse. The year 2013 became 2,676 cases, of which 54 percent were dominated by sexual crimes. Then in 2014 as many as 2737 cases. Abuse cases against children in Surabaya continue to increase. Based on the report of the Child Protection Agency (LPA) of East Java, the increase in abuse against children in Surabaya is significant. Java LPA data details, in 2013, the number of cases of abuse against children in East Java 
reached 563 events. While in 2014, increased to 723 cases. 'Of these, 70 percent occur in Surabaya.

Residents who live in slums or densely populated are vulnerable to abuse against children. Low economic levels make the pressure felt so high. Moreover, the higher level of consumer society makes one more stressful, more difficult to emotionally. When the condition occurs in the elderly, then the child is often the target of anger or emotional outburst. Parents often do not know that the action is a form of domestic abuse (KDRT). Abuse committed, especially in children varies, ranging from harsh words, beatings, not feeding, squeezing out his energy to beg and others.

One corner of the slum location in Surabaya, precisely on the banks of Kalimas River Surabaya also found these things. Most of the inhabitants are scavengers, beggars, pedicab drivers, with non- permanent residences. Therefore this research was focused on that location. The study aims to describe the types of abuse in children, as well as to analyze the social and demographic factors that trigger the occurrence of cases of abuse in children in the environment of Kalimas Surabaya riverbanks.

\section{METHODS}

The research was conducted using qualitative method, with purposive data collection. The data analysis was analytic descriptive. Data obtained through observation, questionnaires / questionnaires, and field interviews are not poured into figures. The results of data analysis are in the form of exposure to some observed variables, and the relationship between these variables.

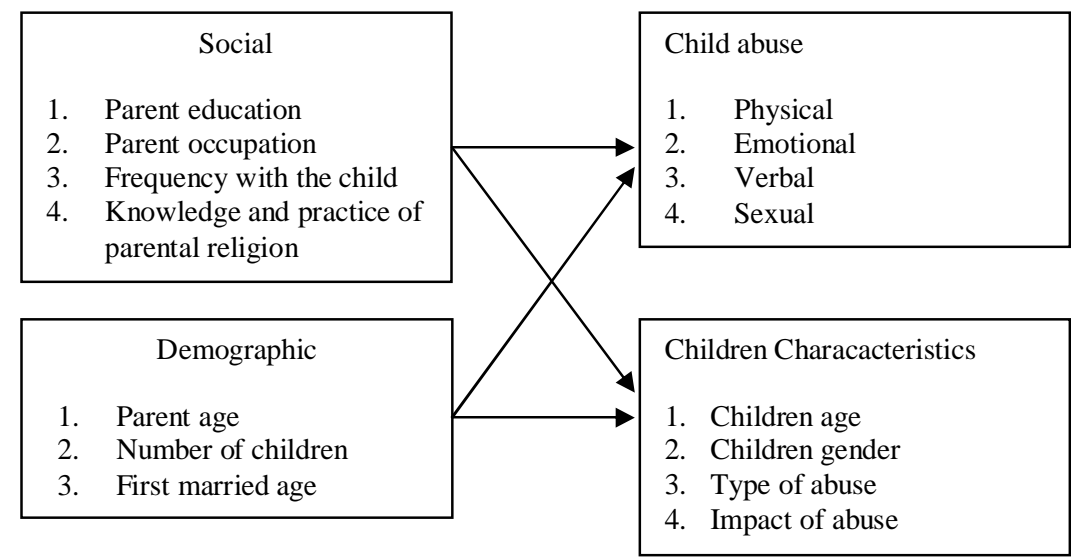

Figure 1

Conceptual framework

Table 1

Research variable

\begin{tabular}{|c|l|}
\hline No & \multicolumn{1}{c|}{ Variables Observed } \\
\hline 1 & Characteristics of Parents (age, gender, religion, ethnicity, final education, occupation, etc.) \\
\hline 2 & Characteristics of children (age, gender, religion, ethnicity, final education, etc.) \\
\hline 3 & Type of abuse received / performed \\
\hline 4 & Child status (biological / not), number of married, first married age, \\
\hline 5 & Knowledge and practice of parent religion \\
\hline 6 & Type of residence \\
\hline
\end{tabular}

\section{A. Child Abuse}

\section{RESULT AND DISCUSSION}

Abuse means torture, torture, or mistreatment. According to WHO (in Bagong S, et al, 2000), abuse is the use of physical force and power, threats or actions against oneself, individuals or groups of people or communities that result or are likely to result in bruising, death, psychological harm, Development or deprivation of rights. The beginning of the term acts of abuse in children or child abuse and neglect known from the world of medicine.

Child abuse are all forms of physical or emotional pain treatment, sexual abuse, trafficking, neglect, commercial exploitation including commercial sexual exploitation of children resulting in real or potential injury / harm to the health of the child, child survival, child development or the dignity of the child,
Conducted within the context of a relationship of responsibility, trust or power. Forms of abuse against children Terry E. Lawson (in Huraerah, 2007), an international psychiatrist who formulates the definition of child abuse, mentions four kinds of abuse: emotional abuse, verbal abuse, physical abuse, and sexual abuse.

\section{Physical Abuse}

Physical abuse, occurs when the parent / caregiver and child protector hit the child (when the child actually needs attention). This abuse will be remembered by the child if the physical abuse lasts for a certain period. Physical abuse includes pinching, punching, slapping, slapping, slapping, lit cigarettes, burning or other physical abuse of a child that can harm and harm a child. 


\section{Psychological/emotional abuse}

Occurs when the parent / caregiver and child protector after knowing the child is calling attention, ignoring the child. Parents let children get wet or hungry because mothers are too busy or do not want to be disturbed at that time. Emotional abuse can also be a neglect where children do not get their rights such as getting education, health, affection and including children who are deliberately exploited for work. The child will remember all emotional abuse if the emotional abuse is consistent. Parents who are emotionally abusive to their children will continue to do the same throughout their lives. Emotional abuse is abandoned, isolated, exploited, and neglected.

\section{Verbal abuse}

Usually in the form of verbal behavior in which the perpetrator performs a communication pattern that contains contempt, or words that harass the child. The perpetrator usually performs a mental act of abuse, blame, labeling, throwing harsh words (gross), or also scapegoating.

\section{Sexual abuse}

Involves coercion of sexual intercourse committed against a person residing within the scope of the household (such as wife, father, child, relative, and domestic worker). It is further explained that sexual abuse is any act of coercion of sexual intercourse, coercion of sexual intercourse in an unnatural and or disliked manner, coercion of sexual intercourse with another person for a specific commercial purpose or purpose. Another behavior that is also categorized as sexual harassment is to deliberately see the child's sexual organs with bad intentions, invite children to see pornographic shows, and touch the child's sexual organs.

\section{B. Social and Demographic Factors}

The urban poor is a tangible form of social inequalities in the equitable distribution of development outcomes. Urban poverty produces complex problems, including low education, quality of life, health status, child exploitation, to domestic abuse (KDRT). From the problem of poverty, women and children are the most vulnerable parties affected because of their position which is often considered weak in the family structure.

The subject of this research is a mother who lived in the slum area precisely in Kalimas River Kalimas Bridges Surabaya. Respondents of this research were mostly low-educated (not graduated from primary school) and some were not in school. Others did not finish primary school, junior high school, and only one high school person. The low level of respondent education is closely related to the poverty level and the low awareness of the importance of education. The average respondent's job was scavengers (garbage, fish, and onions), porters, street vendors, parking attendants and unemployed. The daily work of the respondent did not provide enough income to meet daily needs. So what happened was some respondents told their children to share the burden of the family's economic needs, by joining work. So the work undertaken by children was almost not far from the work done by his parents, namely scavengers, buskers, beggars, motorcycle taxi drivers in the rainy season and pedicab drivers on Jenbatan Merah.

Types of work that were not permanent, informal, and not time-bound, cause the intensity of meeting children more than 15 hours / day, especially with children who are no longer in school (drop-out). But although the intensity of meeting or communicating with parents and children is high, it does not necessarily build a positive relationship between parents and children. This is because parenting and parent's wrong point of view to the child. Children are often positioned as the wrong side, must always be obedient, weak, and parents assume have the right to do anything to children including exploiting children to participate in making money.

Violent child-rearing behavior also can not be separated from the understanding and practice of low parental religion. All respondents are Muslim, from Javanese and Madurese tribes. However, although Muslims, most of the respondents have not performed Islamic religious duties such as the 5 day prayer. Respondents who perform their duties as a Muslim are less than half, and the average of the Madurese. They reside in densely populated rural dwellings that are not far from the banks of Kalimas River Jembatan Merah. While the respondents who live on the bridge of Kalimas Jembatan Merah in the form of tents from tarpaulins that can be dismantled pairs, most of the Tribe of Java and a small part of Madura, almost never / very rarely do prayers 5 times. In addition to the place that is not supportive, the lack of awareness to follow the religious command becomes the main factor of low knowledge and practice of religious duties of parentsThe complexity of the social issue is also related to several demographic-related factors. The average age of respondents is 20 to 45 years. The average married first time at the age of 18 years. There are even respondents who married the first time at the age of 12 years. So what happened in the young age, 26 years, there are respondents who have had 5 children. The average respondent has 2 or more children. And most of the status is a biological child. There was one respondent who picked up a child from his own relative.

The number of marriage cases at an early age (child) at the study site was triggered by many things, including hereditary habits, low levels of education, promiscuity, and poverty. For the poor, marrying a child at an early age means releasing the responsibility of the child to be handed over to others. Marriage at an early age (children) often give birth parents who are not ready in childcare, both economically and mentally. And the consequences often cause new problems, especially if there is a dysfunction in the family such as the relationship of unlawful husband and wife, the husband leave or neglect the child and wife,

Risk of Child Abuse

Referring to forms of abuse against children, Terry E. Lawson (in Huraerah, 2007), who defines the definition of child abuse, there are four kinds of abuse, 
namely physical abuse, emotional abuse, verbal abuse, and sexual abuse. In research conducted found that physical abuse, psychological abuse / Emotional, and verbal abuse dominate the form of abuse, while sexual abuse by parents against children is not found, but sexual abuse behavior is found in other peers.

A form of physical abuse received by a child and done by his or her parents such as being beaten by hand, beaten with blunt objects (sandals, tubs of water, wood), pinched, twisted, slapped, and lit by cigarettes. One child who often experienced physical abuse is Yanti (7 Years). This little girl lived in one of the parking lot, on the banks of Kalimas River Red Bridge with mother, grandmother, cousin, uncle, aunt, and 5 brother 12 years old, 10 years, 5 years, 4 years and 2 years. Forms of physical abuse received by Yanti in addition to being pinched, beaten with empty hands, Yanti also had been thrown with sandals or bags containing ice cubes causing her forehead to bump.

Not only physical abuse, Yanti and her five brothers also often received verbal and emotional abuse from her mother. The emotional and verbal abuse that Yanti and her siblings often received was a curse with dirty and abusive words, like asu (dog), lonthe (prostitute), and bongko (dead). Hard and rough characters of Endang (32 years), Yanti's mother, can not be separated from her role as a single parent, with the burden of 6 children, and left behind by her husband. The heavy burden of living as a single parent, not knowing and carrying out religious teachings, never attending school, and past experiences as victims of violent behavior from her parents, made this mother of 6 children very temperamental and rude to her children.

Ati kulo kesel Bunda, kadang nggih jengkel nek anak dituturi mboten nurut-nurut. Mangkane sing medal omongan elek. Jengkel kulo. Dikandani apik-apik gak nurut, nggih kepekso nggangge omongan kasar, kadang nggih kulo gepuk nggangge tangan, nopo mawon sing teng cedak kulo, mben kapok. Tapi jane kulo nggih ngesakno (Sometimes I get annoyed if they are advised not to obey. That's why the mother's harsh words came out. I am annoyed. They are advised well but not obedient, I was forced to use a rough word, sometimes I hit with my hands or objects that are near me, to be deterrent. But sometimes I feel sorry too). (Interview with Endang, Yanti's mother, 8 June 2017).

While the forms of emotional abuse that occurred were abandon, isolation, exploitation, and neglect. Child neglect by parents are they do not provide enough food, some children have to feed themselves by working, when sick children are not given / not taken to the clinic / hospital / doctor, and parents tend to ignore / let the condition of a sick child while waiting Helping hand from others.

This condition occured in a child named Rian. This child suffered serious injuries in the earlobe. In addition to severe scab in the earlobe, Rian's ear also produced a yellow liquid (congek) that gave off a bad smell. This condition made Rian bullied by his friends and also shunned because of the unpleasant odor that came out of his ears. Although his condition is quite severe, Rian had never been taken for treatment by his parents. As revealed by Linda, Rian's mother as follows:

Mboten enten sing ngeter dateng Puskesmas Bunda..Niki adik'e Rian taksih alit-alit. Kulo repot momong, nggih pados arto kangge nedo (No one escorted to puskesmas. His sister is still small. I bother to take care of children also make money). (Interview with Linda, Rian's mother, 1 June 2017).

Abandonment also occured in the form of children left behind by their parents. And most of what happens is the father figure leaves his son and his wife, to remarry another woman. So what happens is, children are often exploited to work to support the economic needs of the family by working on the streets as street singers, scavengers, beggars, motorcycle taxi drivers in the rainy season, and pedicab drivers on the ramp of Jembatan Merah Surabaya. The neglect of this child had an impact on the education of children in the research location. Most of the respondent's children who live in the huts of Kalimas River tents dropped out (did not want to go to school). The lack of awareness and participation of parents to continue to encourage the sustainability of their children's education is one of the many factors of school dropouts in the region. Children are more likely to be exploited for money. In addition to meeting the needs of families, children are also given the burden of obligation to participate in paying the debts of the parents on the moneylenders.

In relation to education, although many children in this region drop out of school, there are still children who are still consistently continuing their education. From intensive observations and interviews conducted by researchers, children who are still consistent in school although they have to work / earn money are those whose parents have attended school (did not finish primary school, junior high school, or high school) and live in very simple boarding houses . Parents of children who have been educated on average have more awareness and willingness to encourage their children to stay in school. This is as revealed by Mrs. Nur (35 Years Old), mother of Roni, Rizki, Putri, and Berta.

"Pengin anak kulo pinter Bundaa, kersane uripe mboten soro kados kulo. Dados tukang parkir, kerjo serabutan. Mangkane kados nopo mawon kondisine kudu sekolah. Jane nggih mesakke, ningali lare-lare nderek pados arto" ( I want my kids smart. So that life is not as difficult as me. Become a caretaker, work to be anything. Therefore, no matter what the conditions must go to school. Actually I feel sorry to see the children come to work to earn money). (Interview with Ibu Nur. Mother of Roni, Rizki, Putri, and Berta, 5 June 2017).

Verbal abuse comes along with the physical and emotional abuse that the child receives. Abusive, child's self-esteem, inappropriate epithets, negative stigma in the child come into existence when the child experiences physical or emotional abuse. The level of parental education greatly affects how they nurture children. Parents who have attended school, even though they did not finish primary school, junior high school, tend to have a better parenting pattern than 
parents who are not in school. When children make mistakes or commit undesirable actions, parents are more inclined to advise children than to do physical abuse that hurt children. The physical abuse they are forced to do is pinch the child.

While the sexual abuse of parents in children was not found. But cases of sexual abuse in the form of impolite behavior that lead to sexual behavior was actually done a group of children on peers. The perpetrators of this sexual harassment were a group of boys aged 7-12 years on a girl, call it 13-year-old Upik. A group of these boys deliberately uncovered the skirt of the Upik who was fast asleep on the porch of a warehouse on the banks of Kalimas River Jembatan Merah Surabaya. Another form of negative behavior that lead to sexual behavior was when an 11-year-old boy, Mamat, who spoke plainly about adult sexual activity. Negative / distorted behavior in minors found could be because the Mamat had seen sexual activity performed by an adult where he lived. Mamat, Upik, and groups of boys who sexually harassed are groups of children whose parents live in tents made of tarpaulins in the Kalimas Riverbank of the Surabaya Red Bridge.

\section{CONCLUSION}

Parents with low or no education, lack of understanding of religion, heavy economic burdens and heavy or black past backgrounds are more likely to engage in child abuse with more frequent intensity and also to a greater degree of risk and harm to child. Tribes (Javanese, Madurese) do not have a significant correlation with the risk of child abuse. In parents who have low or unfavorable social conditions, abuse in children is not only done in the provision of punishment in determining good with parental standards, but also in other forms of abuse by exploiting children. Exploitation is done by persuading or sending children to work to support the family's economic needs. Some of the exploitation that occurred due to the dysfunctional role of the father as head of the family, either because they have no permanent job, unemployment, or leave the child and his wife to remarry.

The frequency of togetherness between parents and children have no significant influence in determining how the risk of abuse perpetrated by parents in care. The average of the respondents taken in the study sample, has a long time in togetherness with the child. Togetherness with the child does not necessarily increase a close parental affection to the child, but sometimes in the long-standing togetherness of parents with poor social and demographic conditions, increasing the risk of child abuse. This is due to low parental insight about good and right parenting in children. Children with poorly educated / out-of-school parents, no permanent employment, no proper housing, low knowledge and religious practice are more at risk / more likely to experience abuse. Likewise with children whose parents marry young, the number of children and many have a dark past as victims of abuse in the care of their parents, have a greater risk of becoming victims of abuse. Child abuse also causes non-fulfillment of children's access to the right to life, including the right to education services, which causes most of the children to drop out of school.

Children with parents living in huts, or other non-permanent residences, are more at risk of experiencing physical, verbal, emotional abuse with higher impact levels, and are more at risk of sexual abuse and abuse among their friends. This is because their chances of seeing adult sexual activity are greater, and there is no religious or moral education from parents. So the conditions demand the seriousness of society and government to make a strategic effort, actual and real for people who live in slums. And one of the most important things to be a priority is the economic empowerment of society and education.

\section{REFERENCES}

[1] Komnas Perlindangan Anak. 2015. Kekerasan Anak Tertinggi Selama 5 Tahun Terakhir. Retrieved July 6, 2017 , from http://news.liputan6.com/read/2396014/komnas-pa2015.

[2] Kompas. 2014. Mayoritas Anak di Daerah Kumuh di Bandung Jadi Korban KDRT. Retrieved July 6, 2017, from http://regional.kompas.com/read/2014/10/13/19350641.

[3] KPAI. 2014. Undang-undang Perlindungan Anak. Retrieved May 28, 2017, from http://www.kpai.go.id/files/2013/09/uu-nomor-35tahun-2014-tentang-perubahan-uu-pa.

[4] Peraturan Menteri Perlindungan Perempuan \& Perlindungan Anak Nomor 2 Tahun 2010 tentang Rencana Aksi Nasional Pencegahan dan Penanganan Kekerasan terhadap Anak. 2011. Jakarta: Fokus Media.

[5] Peraturan Pemerintah Nomor 20 Tahun 2010 tentang Pemberdayaan Perempuan dan Perlingdungan Anak. 2011. Jakarta: Fokus Media.

[6] Republika. 2015. Kasus Kekerasan terhadap Anak di Surabaya Terus Meningkat. Retrieved July 6, 2017, from

http://nasional.republika.co.id/berita/nasional/hukum/1 5/08/19/ntbvbo350.

[7] Republika. 2011. Lebih dari 20 Juta Anak Masih Alami Kekerasan. Retrieved July 6, 2017, from http://www.republika.co.id/berita/nasional/umum/11/04 /13/ljkxck.

[8] The Foundation for Practice, Office on Child Abuse and Neglect. 2003. Coordinated Response to Child Abuse and Neglect. New York: The Foundation for Practice, Office on Child Abuse and Neglect, USA.

[9] Undang-undang Nomor 23 Tahun 2004 tentang Penghapusan Kekerasan dalam Rumah Tangga. 2005. Jakarta: Fokus Media.

[10] Undang-undang Nomor 23 Tahun 2002 tentang Perlindungan Anak. 2004. Jakarta: Fokus Media.

[11] UNICEF. 2015. Laporan Perkawinan Anak. Retrieved May 28, 2017, from https://www.unicef.org/indonesia/id/Laporan_Perkawin an_Usia_Anak.

[12] Wikipedia. 2017. Kekerasan dalam Rumah Tangga. Retrieved July 6, 2017, from https://id.wikipedia.org/wiki/Kekerasan_dalam_rumah_ tangga diakses 6 Juli 2017. 